\title{
Economic Upliftment and Social Development through the Development of Digital Astuteness in Rural Areas
}

\author{
Antoinette Lombard \\ E-skills Director at Vaal \\ University of Technology, \\ Vanderbijlpark, South Africa \\ Alombard@vut.ac.za
}

\author{
Hein Johan Wiese \\ Economic Development at \\ International Diverse \\ Innovative Solutions (Pty) Ltd, \\ Pretoria, South Africa
}

heinwiese4@gmail.com

\section{Jan Smit \\ Curriculum Coordinator, Faculty of Engineering and \\ Technology, Vaal University of Technology, Vanderbijlpark, South Africa}

jans@vut.ac.za

\begin{abstract} enormous.

Material published as part of this publication, either on-line or in print, is copyrighted by the Informing Science Institute. Permission to make digital or paper copy of part or all of these works for personal or classroom use is granted without fee provided that the copies are not made or distributed for profit or commercial advantage AND that copies 1) bear this notice in full and 2) give the full citation on the first page. It is permissible to abstract these works so long as credit is given. To copy in all other cases or to republish or to post on a server or to redistribute to lists requires specific permission and payment of a fee. Contact Publisher@InformingScience.org to request redistribution permission.
\end{abstract}

One of the key attempts towards a collective African vision is the New Economic Partnership for African Development (NEPAD). Barnard and Vonk (2003) report that "53 countries have been urged to implement ICTs in three crucial development arenas: education, health and trade". While NEPAD and other initiatives have contributed to the provision of ICT infrastructure with positive results as seen in the growth of Internet uses, the disparities in development across Africa are

The challenge to Higher Education Institutions in Africa has been summarised by Colle (2005): "central to creating digital resources and academic infrastructure is the question of universities' relevance to the world around them, and especially to the challenge of being an active player 'an anchor of a broad-based poverty alleviation strategy' in an increasingly knowledge-based economy". It can be inferred from Colle that the activities of HEIs in Africa ought to be geared towards contributing to the realisation of the Millennium development goals.

In 2003, the World Summit on the Information Society (WSIS) adopted a declaration of principles aimed at enabling everyone to create access, utilise, and share information and knowledge. In

this declaration, member states affirmed their commitment to aggressive investment in ICT for social and economic development (Ngwenyama, AndohBaidoo, Bollou, \& Morawecynski, 2006).

Keywords: Economic upliftment, Social development, Digital astuteness, Rural areas. 


\section{Introduction}

The central idea conveyed by this paper is essentially a proposal for an intervention program that is aimed at developing the digital astuteness of rural and less rural areas of South Africa in a bid to contribute to economic upliftment and social development.

The goal of the proposed intervention is to support existing learning programs in South Africa by injecting a flux of digital astuteness into the citizenry. The intervention is brought about by the use of container classrooms, which are extensively discussed, with design schemas proposed as well as other relevant information.

In the South African context, e-skills are broadly defined as the ability of people to use and create all forms of ICT in order to achieve equitable prosperity and global competitiveness in general, and to improve their life opportunities in (i) personal and educational space, (ii) work environments, (iii) community interactions, and (iv) participation in government processes.

Democratic South Africa has made genuine progress in creating a more equitable society by, for example, providing better access to education and training at all levels and continuous improvements to the healthcare system. However, despite the South African Constitution and the international human rights law recognition that everyone has the right to an adequate standard of living, we are still facing conditions which do not sustain the human rights of our citizens and their dignity.

\section{Literature Study}

\section{Contextualisation}

One of the key attempts towards a collective African vision is the New Economic Partnership for African Development. Barnard and Vonk (2003) report that "53 countries have been urged to implement ICT in three crucial development arenas: education, health and trade". While NEPAD and other initiatives have contributed to the provision of ICT infrastructure with positive results as seen in the growth of Internet uses, the disparities in development across Africa are enormous.

The challenge to Higher Education Institutions (HEIs) in Africa has been summarised by Colle (2005): "central to creating digital resources and academic infrastructure is the question of universities' relevance to the world around them, and especially to the challenge of being an active player - 'an anchor of a broad-based poverty alleviation strategy' in an increasingly knowledgebased economy". It can be inferred from Colle that the activities of HEIs in Africa ought to be geared towards contributing to the realisation of the Millennium development goals.

In 2003, the World Summit on the Information Society adopted a declaration of principles aimed at enabling everyone to create access, utilise and share information and knowledge. In this declaration, member states affirmed their commitment to aggressive investment in ICT for social and economic development (Ngwenyama et al., 2006).

In Ghana, one of the reasons for low internet use is lack of access (Colle, 2005). The problem of access to the Internet seems to impact on educators' readiness for preparing graduates who are able to conceptualise the links between ICT and development challenges. Obuobi, Richards, and Adrion (2006) observes that although there are 12 private universities and six public ones in Ghana, there is a critical shortage of highly qualified professionals and teachers in IT to accelerate economic and academic development. In an earlier study, Unwin (2005) reports that approximately 30,000 untrained teachers worked in various schools in Ghana in 2003. In these contexts, the challenge is how to cost-effectively mentor untrained educators without them leaving the class- 
rooms and how to allow educators to access shared resources. The role of ICT for life-long learning becomes evident in such a scenario.

\section{Ineffectiveness of traditional teaching models}

James, Hesselmark, Akoh, \& Mware (2003) note that the model for lecture-based products within the African institutions reviewed has been that of a face-to-face classroom situation, using a variety of media to enhance the learning experience. Thus most of the software packages used in teaching ICT skills are instructor-led as opposed to hands-on practical approaches to learning (James et al., 2003). Other shortcomings exposed in the African learning process include computer use in poorer districts being characterised by drill, practise, and remediation. This method has proved to have negative results for students when used beyond primary education (Coupe, Goveia, Haichour, \& Ilukena, 2003).

There has been an innovative approach from SchoolNet, South Africa Educator Development Network which has been more practical. This approach is currently being investigated in learning institutions in South Africa, with the teaching of ICT skills being approached differently, driven by the assumption "that it can be learnt incidentally while focusing on specific education-related tasks and themes" (James et al., 2003).

James et al. (2003) look at a 10-20 year perspective and predict ICT resources being widely available for communication purposes throughout Africa, with computer literacy, which include knowledge about more sophisticated office applications, such as databases, document production, spreadsheet usage and specific applications for multimedia, administrative and technical uses.

As the technology advances, users will find the technology increasingly easier to use and it is likely that little computer literacy will be needed to use the future communication devices. What becomes important is how to use the technology effectively, rather than "what makes this computer/software work?" (James et al., 2003).

There is common understanding among the developed and developing countries that development of the knowledge-based and innovation-driven economies and societies is not possible without having highly skilled (e-skilled) ICT knowledge workers and digitally literate (e-literate) citizens (as consumers, clients, participants, friends, families, and communities). ICT -related knowledge, skills and competences (also referred to as e-competences) are critical for the growth of "new age" economies that indispensably require innovation and aggregation of resources, to achieve global competitiveness.

\section{The Current Situation}

The National Development Plan (NDP) of the South African government outlines an e-literate South Africa by 2030. To achieve this means embedding e-astuteness into South African consciousness across the entire country, the Ikamva National e-Skills Institute (iNeSI) has developed a framework that focuses on five primary areas.

These refer to multi-stakeholder collaboration which involves partners across Government, Business, Government agencies and State owned entities as well as global development partners and agencies, continental and international partners, communities, organised labour and education including universities, technical and vocational education and training colleges (TVET) and schools both public and privately owned.

The second primary area identified is Aggregation which refers to a concerted effort for an integrated service delivery, resources for optimal efficiency, strategies and policies for a systemic implementation of the e-skills agenda, "Big Data" analysis in the context of research to devise 
best practices and lessons learnt to support evidence-based policymaking and monitoring and evaluation (NESPA, 2012).

The third primary area identified is e-Astuteness which is a term "closely related to developing ecompetent individuals by giving them appropriate ICT-related knowledge and skills and training them to develop a competent attitude and knowledge to use and to adapt to the rapidly changing new forms of ICT devices and associated software" (Mitrovic, Taylor, Sharif, Claassen, \& Wesso, 2013). This area leads to e-Social Astuteness which "denotes a smart way of applying acquired e-skills and e-Astuteness for everyday socio-economic development and better life opportunities for local benefit in a socio-economic dynamic increasingly impacted by new forms of ICT" (Mitrovic et al., 2013). This is related to a process of (i) involvement in a net-work of social interactions, established through the learning centres, (ii) having a collective level of awareness and understanding diverse social situations, (iii) the identification of socio-economic needs and opportunities that could be met with ICT enabled applications, such as job applications and the creation of $\mathrm{CVs}$, etc. (iv) the examination of various alternatives that could lead to economic upliftment, (v) the development, testing and modification of options, (vi) the assessment of 'fit' of value proposition i.e. success or failure and applicability and (vii) network supported adoption and scaling (Mitrovic et al., 2013).

Research and Innovation is to look for appropriate and innovative ways to address systemic problems and other inefficiencies and weaknesses in achieving learning success. This would include finding ways to identify entrants with potential that do not have the normally required entrance qualifications, supporting under-prepared students, and introducing work integrated learning and practical components into programmes. It will provide a focus for continuous research in a transdisciplinary manner to concentrate on new ways to embed technology into people's lives to improve business opportunities, access government services and build social cohesion; manage evidence-based research and development for a collaborative knowledge economy to address the national goals as reflected in the National Development Plan (NDP, 2011) (MTSF 2009).The goals will be realised by strengthening the national e-Skills Research Network (ResNES); host an annual research colloquium; and provide for the establishment of research chairs to support the national thematic areas of the provincial Collaborative Laboratories (CoLabs).

Advocacy and Awareness is to develop a national awareness campaign that will gain the understanding, support and recognition from the highest levels of Government, Business, Education, Civil Society and Organised Labour. It will involve all available channels.

Given the mandate of the NDP, to ensure South Africa is e-literate by 2030, Vaal University of Technology (VUT) is in the process of rolling out a national training intervention. This will take the form of a self-taught online e-literacy programme in combination with a facilitator in a local economic development training environment - followed by a work readiness programme. The eliteracy programme has been developed with an integrated curriculum that covers topics such as internet and email, mobile applications, introduction to computers, computer functions, word processing, spread sheets, and presentations - it is also accredited by the Media, Information and Communication Technologies, Sector Education and Training Authority, and approved by the Vaal University of Technology. The work readiness programme teaches individuals the steps needed to find employment, including CV creation, finding a job, preparing for the interview, etc.

The stakeholders are in the process of finalising a systematic rollout of these learning programmes, which will see training courses conducted in a network of training centres in the periurban areas, which are collectively managed by a Non-Governmental Organisation with experience in this field. To show impact on this project, the reach would need to be extended to the rural areas of the country - the areas in which the unemployment is at its highest. This would 
include the rural areas of Mpumalanga, Limpopo and the North West Province - as well as less rural areas such as Secunda.

The areas classified as rural are devoid of developed towns and cities, which in turn mean there are little to no established training centres or schools through which the individuals in the area can gain access the above-mentioned training. The quickest means of enabling these communities with the critical life changing skills would be through the implementation of "Container Classrooms" - these being containers that have been converted to accommodate all facilities required for classroom training.

The project would aim to see the community engaged in this initiative in various ways, including the management by resources employed out of the communities. The project would seek to build sustainability around these classrooms by empowering the communities as far as possible when it comes to the operations, but also through the provision of services that enable the community in all ways. The use of the classroom should be the beginning functionality of these structures, thereafter the project would push to see cinemas and internet centres start in these structures.

\section{Methodology}

The methodology followed in this project is to implement training pertaining to basic skills - beginning with digital literacy but "growing" into work readiness, basic English competence, Cyber security, and other associated skills in the deep rural areas of Secunda, Mpumalanga, Limpopo, Northern Cape, Eastern Cape and the North West Province of South Africa.

This will be achieved through the following main activities:

\section{Site Development}

The site development would be based on the implementation of 7 converted shipping containers as training centres in the deep rural areas of each of the 6 areas specified above. Associated with this rollout would be the provision of a flat surface for the classroom, a "lean to" for the provision of shade, security fencing, and other infrastructure requirements. A focal objective would be the involvement of the communities in this project to develop a sense of ownership and empowerment - the sustainability of the project is centred around the community adopting this centre and growing the services offered in accordance to their specific need. A consultant or contractor will need to be appointed by the VUT CoLab to manage the project from conception to completion. An initial cost for the implementation of 35 containers as well as the operational expenses has been calculated.

\section{Stakeholders}

The stakeholders in the project should be as far reaching as possible and as inclusive as possible. Some of the role players involved will be the National Electronic Media Institute of South Africa (NEMISA), the VUT as the CoLab of NEMISA, Knowledge Partners as the developer and supplier of the e-literacy software and acting as project management agency of the entire project, Goal2Work which would partner in work readiness training, Siyafunda as an active partner in the training and management of the centres and the Communities in the areas mentioned above.

\section{Infrastructure}

The infrastructure components that will form part of this project would be the use of fully converted shipping containers, which would serve as a classroom structure including doors and windows. This structure would also contain a solar enablement with power connections and DC batteries and backup Generators to supply the necessary electrical needs. Wi-fi connectivity, com- 
puters, whiteboards and data projectors and screens as well as desks and chairs for the participants should be supplied. Air-conditioning of the facilities is also of utmost importance. Furthermore, paving, fencing and security as well as shade cover over the container should be supplied

Figure 1 shows the schematic of the inside of the perceived classroom container.

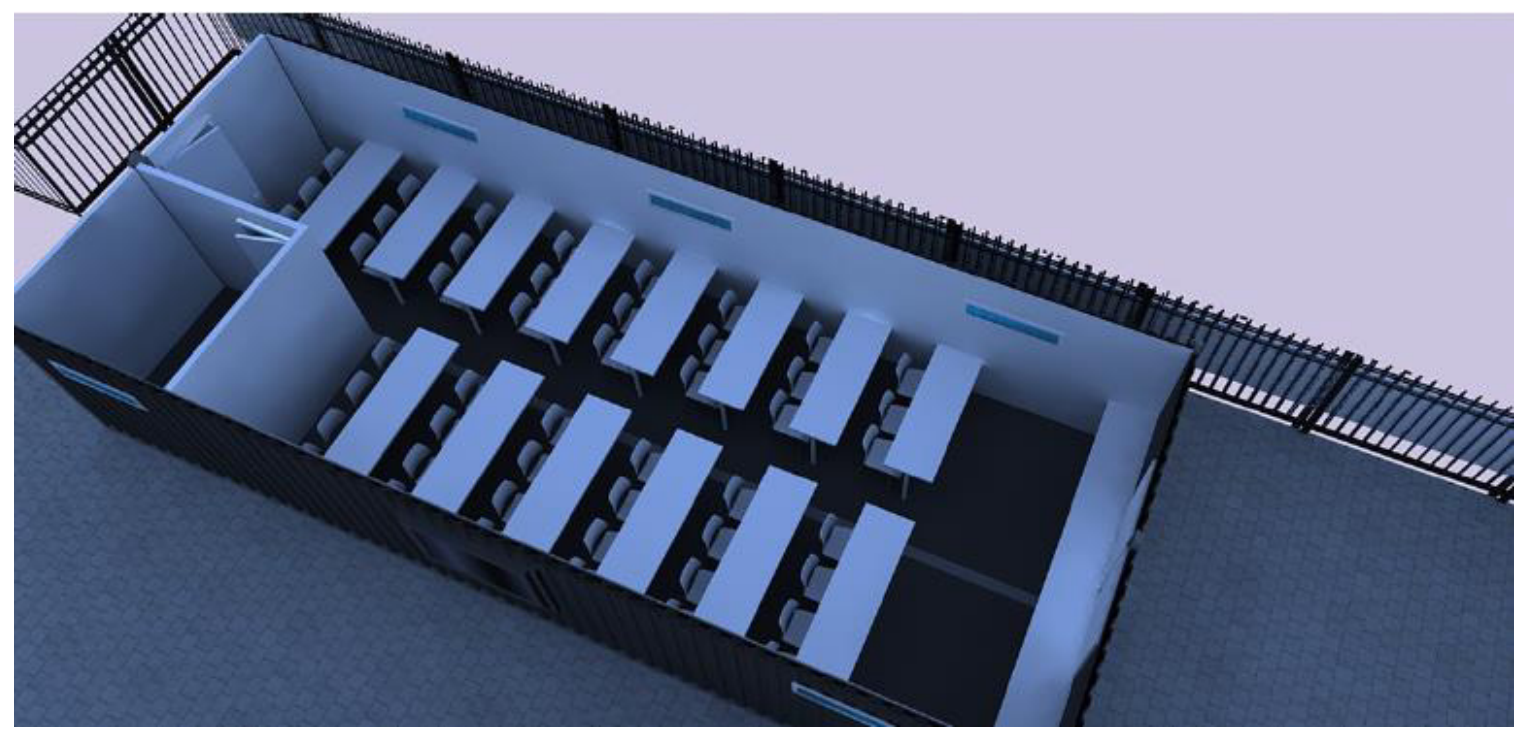

Figure 1. Schematic of inside of perceived classroom container

Figure 2 shows a schematic of the perceived classroom container together with the shading cover, paving and security.

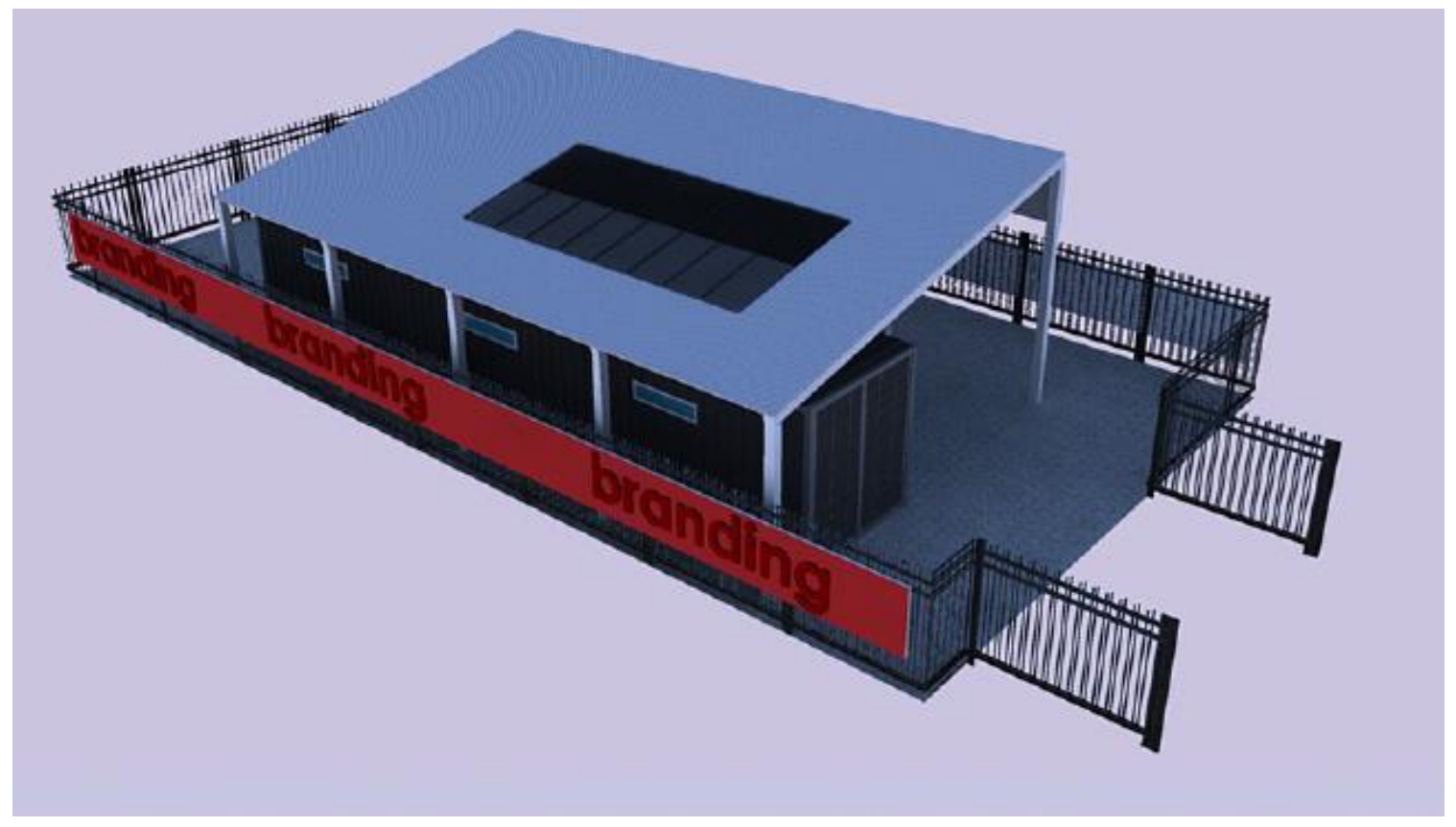

Figure 2. Schematic with the shading cover, paving and security 


\section{Systems and Operations}

The VUT as the CoLab will be responsible for the project but will form a strategic partnership with an organisation called Siyafunda for the daily operations of the training facilities. Siyafunda will be responsible for engaging directly with the community to ensure that the training solution run in these classrooms meet the needs of the communities. They will capacitate the facilities through employment from the community as well as the marketing of the facility directly to the community ensuring the necessary selections of individuals are that are touched through the project. Siyafunda will seek to create sustainability through the engagement with the communities, making sure there is provision of services that will see the initiative adopted and maintained.

The VUT CoLab will be responsible for the systems, processes, and project management within the project - customising each to suit the individual communities. A detailed project management plan will be designed for each classroom, particular to the area - covering the entire process from implementation to initial engagement and beyond.

These centres will lead to specific linkages and interdependencies around the centres. The placement of the container class rooms in secure environments where the security of the infrastructure and the communities can be provided is of utmost importance.

Some of the links that should be established include access to public amenities in close vicinity to the centre. Typical sites where the "class rooms" can be placed should include the use of school yards and the campuses of TVET colleges. Other possibilities are municipal offices or community halls and other government properties such as South African Police Services, national and provincial departments of state departments.

If the placement of the "class rooms" can be located at such venues, there will be no additional need for interdependencies of road networks, water or electricity provision.

The implementation agency for this project will be International Diverse Investment Solutions (IDIS) and VUT.

Certain risks in the project have been identified. These would include among others theft and vandalism of equipment if the fencing and security systems are not provided and occupational health and safety of staff of the contractor and staff operating the "class rooms".

\section{Results}

As this project is in a conceptual phase no real results have been obtained. However, certain key performance measures have been identified. These would include the adoption by the community of the classroom to facilitate the learning of all aspects from digital literacy through to conversational English. Each classroom should successfully train 430 students in a 12 month cycle, making a total of 15050 individuals trained across all classrooms. Each classroom should provide a point of access for the communities to have access to connectivity and power. Furthermore, sufficient staff will be required for resourcing the classrooms and management of the centres on a cyclic annual approach so as to empower new individuals every year. Routine maintenance on the classrooms should be performed to ensure that they remain in optimum condition as well as ensuring that hardware and software are kept updated. Security should be sufficient to prevent security breaches.

\section{Summary and Conclusion}

The creation of digital opportunities within all sectors as a long term approach is essential for socio-economic development of South Africa. International Cooperation and efforts in these directions over the past years have started to produce results by narrowing the digital divide in South 
Africa and other developing countries. It has been quite rapid because of the benefits attained from sharing the knowledge and collaborating. It requires even more efforts and cooperation to sustain as well as keep up with the pace of narrowing the Digital Divide by improving access and education, ensuring further research and development in e-skills and e-astuteness activities. Attractive multimedia based curricula and pedagogy should be implemented using local content so as to make the material acceptable to the community. Efficient production and business processes should be implemented to ensure delivery of public services and reliability of data that is collected and disseminated in all sectors for better planning.

It is obvious that these may be the areas which do not directly contribute to the economic growth but indirectly these are the areas which will help in eradicating poverty, creating and accessing economic opportunities and at the same time sustainability and adaptation, which is the key for success in the Knowledge Economy which could be supported by these centres.

\section{References}

Banard, D., \& Vonk, T. (2003). Information and communication technologies in African local governments. EDITOSIA - Electronic Distance Training on Sustainability in African Local Governments. ICLEI European Secretariat GmbH. Freiburg, Germany.

Colle, R. D. (2005). Building ICT4D capacity in and by African universities. International Journal of Education and Development using Information and Communication Technology (IJEDICT), 1(I), 101107.

Coupe, J., Goveia, J., Haichour, H., \& Ilukena, A. (2003). Is constructivism universal: In search of meaningful technology in Morocco and Namibia. In D.W. Chapman \& L. Mahlck (Eds.), Adapting technology for school improvement: A global perspective. UNESCO/IIEP. Commision Staff Working Document. (2003). Linking up Europe: the importance of interoperability for e-governance services, Brussels.

James, T., Hesselmark, O., Akoh ,B., \& Mware L. (2003). Review of basic ICT skills and training software for educators in Africa. IMFUNDO. Available at http://imfundo.digitalbrain.com/imfundo/web/papers/ictreviewfolder/Final\%20Report.pdf

Mitrovic, Z., Taylor, W., Sharif, M., Claassen, W., \& Wesso, H. (2013). E-social Astuteness skills for ICTsupported equitable prosperity and a capable developmental state in South Africa. International Journal of Education and Development using Information and Communication Technology (IJEDICT), 9(3), 103-123.

MTSF. (2009). Together doing more and better, Medium term strategic framework, A framework to guide Government's programme in the Electoral mandate period (2009 - 2014). Department of Communication, Pretoria, South Africa

NDP. (2011). National development plan. vision for 2030. Government of the Republic of South Africa. Pretoria. Retrieved on 18 January 2016, from www.poa.gov.za

NESPA. (2012). The national e-skills plan of action. The Department of Communication, South Africa, Retrieved on 18 January 2016, from www.doc.gov.za

Ngwenyama, O., Andoh-Baidoo, K. F., Bollou, F., \& Morawecynski, O. (2006). Is there a relationship between ICT, Heath, Education and Development? An empirical analysis of five West African Countries from 1997-2003. The Electronic Journal on Information Systems in Developing Countries (EJISDC), 23(5), 1-11.

Obuobi, D., Richards. W., \& Adrion K. W. (2006). Applying information technology to improve teaching and learning in an African university. The 36th ASEE/IEEE Frontiers in Education Conference. M4C22. San Diego, CA.

Unwin, T. (2005). Towards a framework for the use of ICT in teacher training in Africa. Open Learning, 20(2), 113-129. 


\section{Biographies}

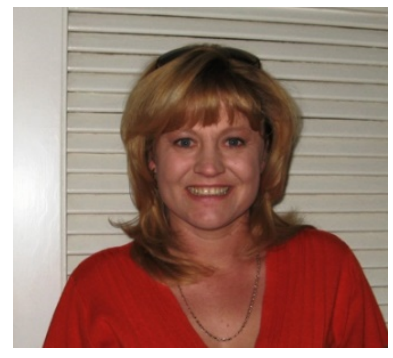

Mrs Antoinette Lombard was born in Vereeniging, Gauteng in South Africa. After completing school studies, she enrolled at the then called Vaal Triangle Technicon to complete a diploma Financial Information Systems in 1994.

She continued her studies and completed her Baccalaurees Technologia Information Technologia (BTech) Financial Information Systems and Magister Technologia (MTech) Information Technology in 2006. She is currently enrolled for her DTech IT.

She was the Head of Department of the Information \& Communication Technology (ICT) Department at the Vaal University of Technology from 2005 until 2015. Before becoming an HOD she was a lecturer in the same department. Ms Lombard was recently appointed in a new positon as Director: E-skills responsible for a national Government project in rolling out e-skills to the nation and institutionalizing e-skills at VUT. She is a board member of HEICTA (Higher Education Information \& Communication Technology Association) of South Africa and an active member of various South African Technology Network (SATN) committees. Curriculum Development, Teaching and Learning Technologies and Quality Management are among her specialities.

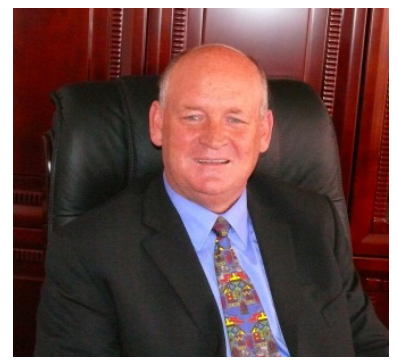

Dr Hein John Wiese was born in Cape Town, Western Cape Province in South Africa. After completing school studies, he enrolled at the Free State University in Bloemfontein to complete a Baccalaureus Commercii in Economics and Money and Banking (B Com), Honneurs Baccalaureus Commercii in Money and Banking and Magister Commercii in Economics. He holds a Doctor Commercii in Economics from the University of Pretoria in Pretoria. He also holds a Certificate Programme in Management Development for Municipal Finance from the University of the Witwatersrand in Johannesburg.

Dr Wiese was a researcher in the Economic Department of the South African Reseserve Bank before joining the Industrial Development Corporation of South Africa as Manager in the Economic Research and Development Department from 1980 to 1994. Hein was a Principal Consultant at Ernst \& Young; Associate at Africon Engineering Services; Head Strategy at i-Commerce Services at Dimension Data; Deputy Municipal Manager: Economic Development at the City of Tshwane Metropolitan Municipality and Deputy Municipal Manager: Economic Development at Emfuleni Local Municipality. Hein was from 2013 until 2015 involved at the Vaal University of Technology in Vanderbijlpark at Director: e-Skills.

Hein is currently Director: Economic Development at International Diverse Innovative Solutions (Pty) Ltd, a company sourcing international funding based in Pretoria. 


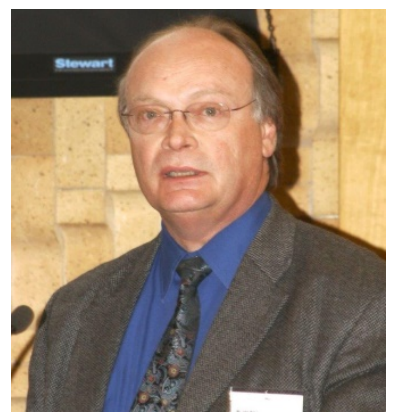

Jan Smit is the Director: Curriculum Development for the Faculty of Engineering and Technology at the Vaal University of Technology. He has been in Higher Education since 1981 as Senior Lecturer Metallurgical Engineering until 2002 when he was re-appointed in his current position.

Dr Smit was a member of the Committee for Tutorial Matters of the Department of Education task team on Modularisation that set up the guidelines for Modularisation of the then Technikon programmes. He is also a member of the National Workgroup on Curriculum Development and as such has facilitated various workshops at different Universities and Universities of Technology throughout South Africa on the process of Modularisation and the implementation of Outcome Based Education in Higher Education.

Dr Smit is an Executive member of the South African Society for Cooperative Education (SASCE) involved in the project which investigates work integrated learning as part of the Higher Education Qualifications sub-Framework (HEQsF) and the implications thereof. He has delivered various national and international papers on Modularisation, Assessment and outcome-based education in Higher Education.

He holds a Masters degree in Metallurgical Engineering from the Vaal University of Technology as well as an MSc in Materials Science from North West University and a Masters Degree in Education from North West University. Dr Smit also holds a PhD in Education (Teaching and Learning) from North West University and an Advanced Diploma in Higher Education from the University of the Free State. 